Check for updates

Cite this: RSC Adv., 2019, 9, 28171

Received 16th June 2019

Accepted 22nd August 2019

DOI: $10.1039 / \mathrm{c} 9 \mathrm{ra04518j}$

rsc.li/rsc-advances

\section{Peptidoglycan pathways: there are still more!}

\author{
Ahmed M. Helal, ${ }^{a}$ Ahmed M. Sayed, ${ }^{a}$ Mariam Omara, ${ }^{a}$ Mohamed M. Elsebaei (D) a \\ and Abdelrahman S. Mayhoub (iD *ab
}

The discovery of $3^{\text {rd }}$ and $4^{\text {th }}$ generations of currently existing classes of antibiotics has not hindered bacterial resistance, which is escalating at an alarming global level. This review follows WHO recommendations through implementing new criteria for newly discovered antibiotics. These recommendations focus on abandoning old scaffolds and hitting new targets. In light of these recommendations, this review discusses seven bacterial proteins that no commercial antibiotics have targeted yet, alongside their reported chemical scaffolds.

\section{Introduction}

It is apparent that currently approved antimicrobials are losing the anti-resistance battle against multidrug-resistant pathogens (MDRP). Microbial resistance has extended to include reagents once deemed to be last resorts, such as vancomycin, ${ }^{\mathbf{1}}$ linezolid, ${ }^{2}$ and even colistin. ${ }^{3}$

To avoid the rapid development of microbial resistance against upcoming antibiotics, the World Health Organization $(\mathrm{WHO})^{4}$ has set innovation criteria to maintain antibiotic clinical efficacy over an extended period. ${ }^{4}$ These criteria mainly include hitting new microbial pathways through novel chemical scaffolds.

This review sheds light on genuine bacterial pathways that have not been targeted with any commercial antibiotics, and

${ }^{a}$ Department of Pharmaceutical Organic Chemistry, College of Pharmacy, Al-Azhar University, Cairo 11884, Egypt. E-mail: amayhoub@azhar.edu.eg

${ }^{b}$ University of Science and Technology, Zewail City of Science and Technology, Giza, Egypt provides examples of those potential antibacterial leads through a structure-based approach.

\section{Targeting peptidoglycan}

\subsection{Biological importance}

Peptidoglycan (PG) is a single macromolecule; however, it surrounds bacterial bodies to grant them integrity along with protection, resulting in it being a key player in the survival of all prokaryotic pathogens. ${ }^{5}$ Consequently, focusing on the PG biosynthetic pathway is favorable for medicinal chemists, since the peptidoglycan bacterial cell wall does not exist in mammalian cells. Moreover, it is multilayered and thicker in Gram-positive bacteria, weighing about half of the dry weight of some types of Gram-positive bacteria. ${ }^{5}$ On the other hand, PG is thinner in Gram-negative bacteria, which are protected by an outer cell wall. ${ }^{6}$ The differences between Gram-positive and Gram-negative bacteria in addition to their results in relation to inhibition and resistance will be discussed below, respectively.

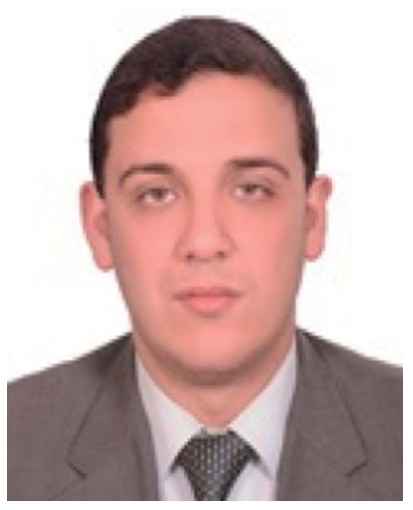

Ahmed Helal (MSc) is a PhD candidate at Dr Mayhoub's laboratory. His thesis focuses on the development of new therapeutics for the treatment of MDR-pathogens. Before joining Dr Mayhoub's lab, he obtained his MSc in Organic Chemistry from Al-Azhar University in 2016. His research interests focus on heterocyclic synthesis.

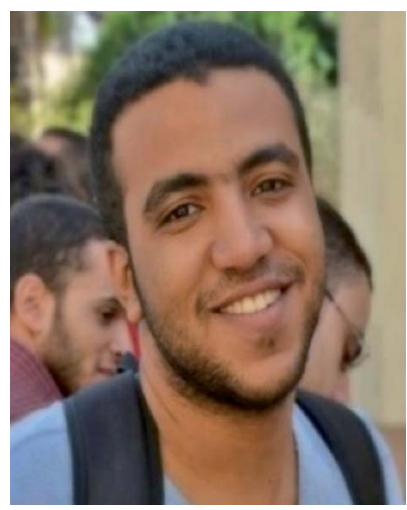

Ahmed M. Sayed is currently working as an $R \& D$ specialist in an Egyptian local pharmaceutical company, where he is following his passion for learning every day. He graduated from Al-Azhar University with a BSC in pharmaceutical sciences in 2017. He joined $\mathrm{Dr}$ Mayhoub's lab as a researcher in 2016 while he was an undergraduate. He feels like he is still not content with his level of education and has to go further in pursuit of knowledge. 


\subsection{Structure}

Chemically, PG includes short chains of glycans and alternative $N$-acetylmuramic acid (MurNAc) and $\beta-1,4-N$-acetylglucosamine (GlcNAc) components, connected via pentapeptides (MurNAcGlcNAc-pentapeptide). ${ }^{7}$ The detailed biosynthetic pathway has been covered in many reviews and articles previously. ${ }^{8-12}$ In Fig. 1, we simplified the PG biosynthetic pathway with a focus on the lipid carrier as a promising target for future antibiotic development.

Remarkably, there are different steps in the PG biosynthetic pathway take place at different cellular levels. The process starts in the cytosolic region via the synthesis of sugar-pentapeptide units, which then relocate through the cytoplasmic membrane to polymerize with other sugars and finally cross-link together to generate the PG molecule (Fig. 1). Nevertheless, all existing antibiotics, perturbing the cell wall synthesis, target either a cytosolic step ${ }^{\mathbf{1 3}}$ or the growing proPG. ${ }^{\mathbf{1 4}}$ Except for the locally acting antibiotic bacitracin, ${ }^{\mathbf{1 5}}$ which interferes with the carrier lipid, this step of PG biosynthesis has somehow been overlooked by medicinal

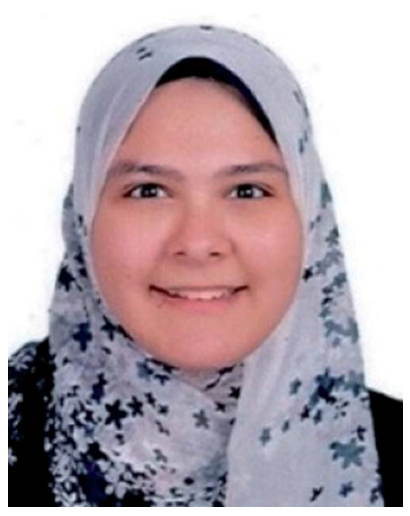

Mariam Omara is a new MSc student in Dr Mayhoub's lab; however, she joined the lab early while she was a sophomore undergraduate. She obtained her BSc in Pharmaceutical Sciences from the College of Pharmacy, AlAzhar University, obtaining the highest Honors degree, in June 2019.

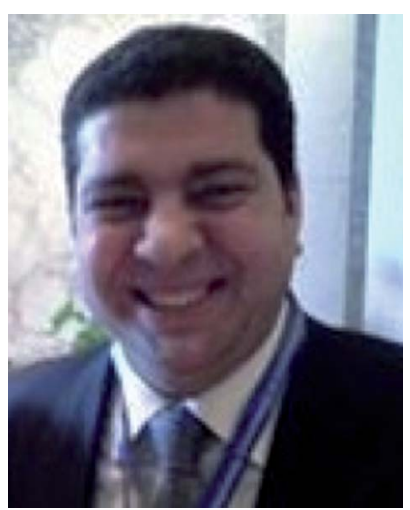

Mohamed M. Elsebaei (PhD) is a lecturer of Organic Chemistry at Al-Azhar University, College of Pharmacy. He obtained his $\mathrm{MSc}$ and PhD in Organic Chemistry, under the supervision of Dr Mayhoub, from the same University in 2015 and 2018, respectively. His research interests focus on cross-coupling reactions, metal-catalyzed reactions, and heterocyclic scaffold design. chemists for decades. In the following section, we will discuss targets within the carrier lipid that bode well for developing novel antibiotics.

\subsection{Extracytoplasmic steps}

2.3.1. Targeting the lipid II pathway. The role of lipid II in PG biosynthesis was explained in a recent review by Dr N. Strynadka. ${ }^{11}$ As noted in Fig. 2, the final step of PG biosynthesis is ultimately carried out by two enzymes: the peptidoglycan glycosyltransferase, which catalyzes lipid II polymerization to form a linear chain, and a transpeptidase. ${ }^{\mathbf{1 6 - 1 8}}$ Thus, lipid II units are a target of glycopeptide antibiotics like vancomycin, to pause further steps of polymerization. ${ }^{16,19}$ As a result of the bacterial resistance that has developed against all these cell wall inhibitors, the need to target the glycosyltransferase (GT) has surfaced. Despite the early discovery of this enzyme, ${ }^{20}$ there is no antibacterial compound for human use that inhibits the GT directly. ${ }^{21}$

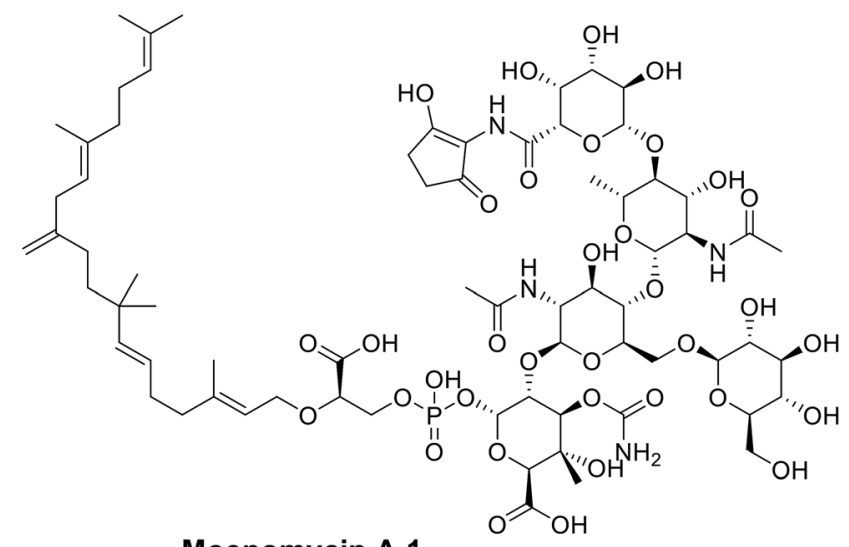

Moenomycin A 1

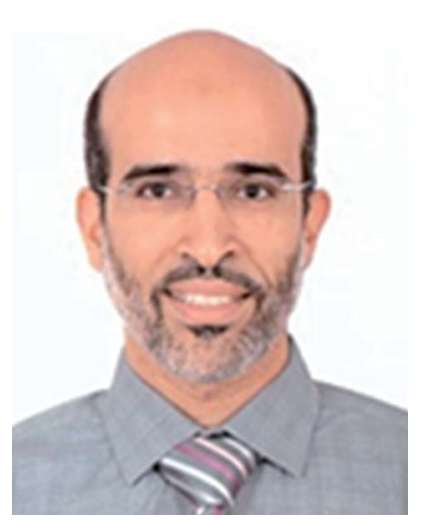

Dr Abdelrahman S. Mayhoub holds a PhD degree (2012) in Medicinal Chemistry from Purdue University, USA. He was a postdoctoral fellow at the University of Michigan (2013) and currently he is an associate professor at Al-Azhar University and Zewail City for Science and Technology (Egypt). His main contributions in the field of Medicinal Chemistry include the development of several cancer chemopreventatives, aromatase inhibitors, and antiflaviviral agents (Dengue and West-Nile viruses). He discovered phenylthiazoles as a new antibacterial class of compounds for the treatment of notorious bacterial strains such as MRSA, VRSA, and VRE. Dr Mayhoub places a special focus on drug-likeness and controlling the pharmacokinetic profiles of bioactive molecules. 


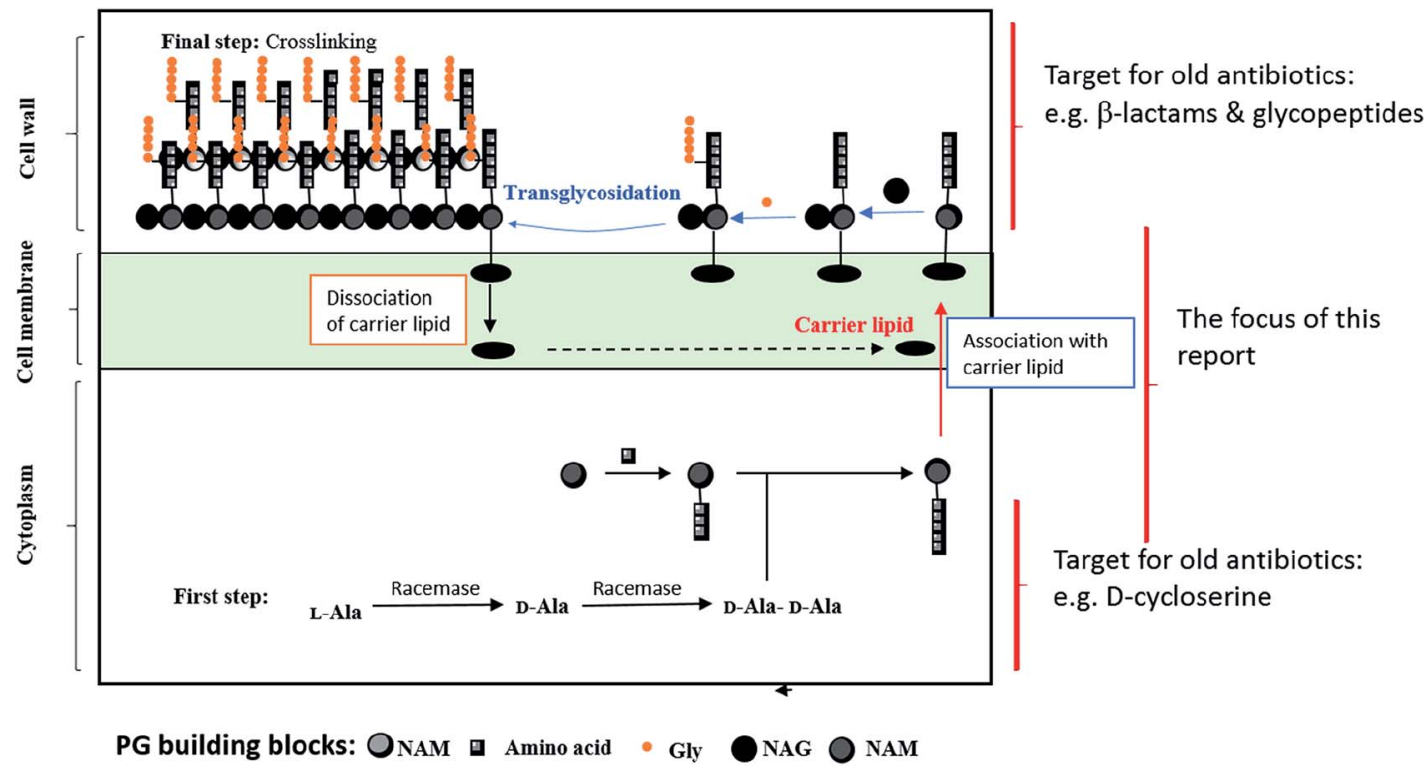

Fig. 1 A diagram showing PG biosynthesis.
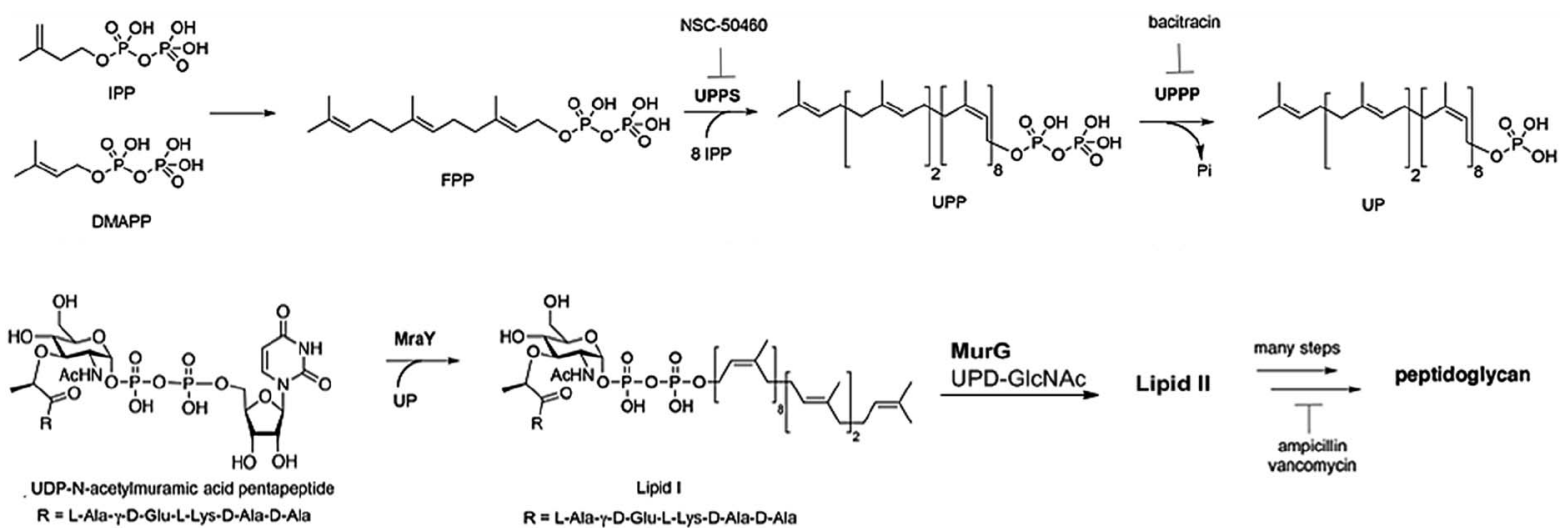

Fig. 2 A schematic illustration of some key steps of PG biosynthesis. Reprinted with permission from Mohammad H., et al., J. Med. Chem., 2017, 2425; copyright: ${ }^{121}$ American Chemical Society.

Moenomycin $\mathbf{1}$ is a natural product that inhibits the GT;22 therefore, it is considered one of the most active antibiotics (MIC $=0.05 \mu \mathrm{g} \mathrm{ml}{ }^{-1}$ for $S$. aureus). Bacteria have shown no resistance against moenomycin, ${ }^{23,24}$ despite its use as a growth promoter in animal feed, which was supposed to provoke resistance. ${ }^{25,26}$ Moreover, resistance induction in vitro showed slow rates of resistance development, ${ }^{27}$ the absence of cross resistance ${ }^{28}$ and a lack of transferable resistance. ${ }^{29}$ Nevertheless, it is not used as an antibiotic as a result of its poor pharmacokinetics profile by virtue of its lipophilicity leading to adverse effects. ${ }^{10,30}$ Recent approaches for targeting the GT include:

- Moenomycin analogues that can bind to the donor part of the receptor, but with better pharmacokinetic profiles. As moenomycin is a pentasaccharide compound linked to a polypernyl chain through a phosphoglycerate linkage, it mimics lipid II through binding competitively to the GT. Hence, there have been several attempts to build moenomycin-like structures.
The first try included simplifying the polysaccharide part of moenomycin via building a disaccharide derivative. This approach resulted in some compounds with good $\mathrm{IC}_{50}$ values (the concentration of an inhibitor where the response (or binding) is reduced by half) on an in vitro scale; however, they did not show in vivo activity, such as in the case of compound $2 .^{21,31-34}$

The second try was to directly mimic lipid $\mathrm{II}^{35}$ or ring $\mathrm{F}$ of the moenomycin, ${ }^{36}$ which resulted in low to moderate activity compounds like compound 3 with an MIC (minimum inhibitory concentration) of $60 \mu \mathrm{M}$ against Bacillus cereus. ${ }^{35}$

Additionally, several articles relied on HTS (high throughput screening) or in silico protocols to generate new leads. Despite advances in obtaining novel leads with apparently potent in vitro activities, none of the tested new structures were efficient in in vivo models. ${ }^{37-40}$

Furthermore, monosaccharide-based scaffolds (e.g. compounds 4 and 5) maintain the essential features of moenomycin with better physicochemical properties and 


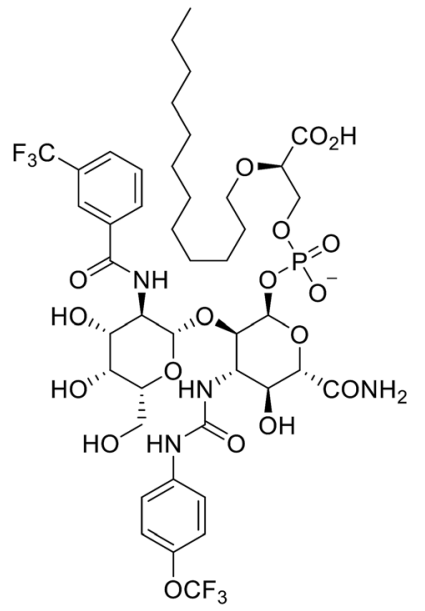

Disacharide moenomycin analog 2

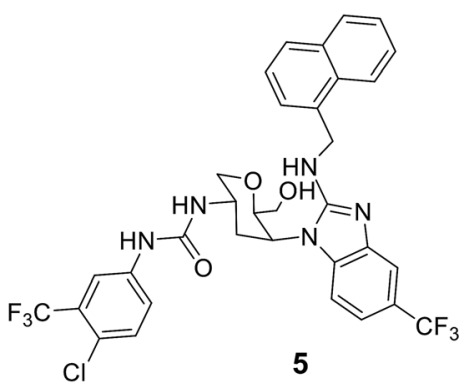

antimicrobial efficacies (MIC values of around $2 \mu \mathrm{g} \mathrm{ml}^{-1}$ against Gram-positive pathogens). ${ }^{21}$

- A recent approach was to create a lipid II analogue in an attempt to imitate the transition state of the GT catalyzed reaction; hence, the compound could bind to the acceptor site of the receptor. ${ }^{34}$

- Researchers managed to synthesize a pseudo-disaccharide lipid II analogue, 6 , to inhibit $70 \%$ of the GT enzyme activity, advancing bacterial cell lysis. ${ }^{30}$

\subsubsection{Targeting $\mathrm{MraY}$}

2.3.2.1. The biological importance of MraY. Bristol-Myers Squibb has shown that mraY (mra: murein synthesis gene cluster-A) is an essential gene in Streptococcus pneumoniae via a gene knockout approach. ${ }^{\mathbf{4 1}}$ Moreover, investigations through genetic and biochemical methods have substantiated that mraY and murG gene products in E. coli are essential for cell growth and survival. ${ }^{42,43}$ This discovery originated from an influx of data about translocase I, a lipid I precursor, dating from the year 1965. However, a leap in knowledge occurred in 1991 when Ikeda et $a l .{ }^{44}$ were able to solve the mystery of the MraY gene sequence, which was officially attached to lipid I production 20 years later. ${ }^{20,45}$

Ultimately, MraY has gained its importance as a result of it not only being a prime molecular enzyme intervening in the prokaryotic cellular envelope, but also because it has no twin in mammalian cells. ${ }^{46}$ Therefore, it is deemed to be an attractive target for antibiotic development. Here, we focus on related discoveries, as well as the implications and challenges related to developing such inhibitors.

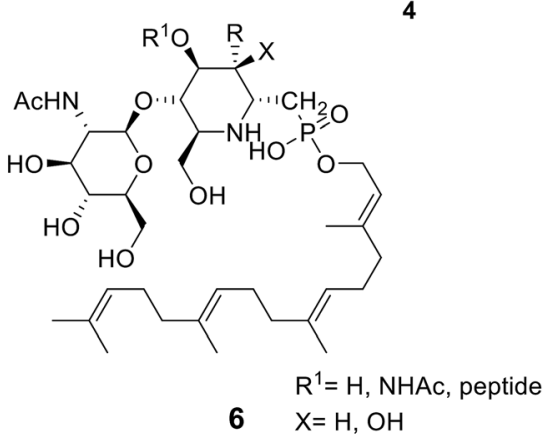

2.3.2.2. MraY inhibitors. So far, only a few classes of MraY inhibitors have been studied, due to difficulties in administering antibacterial compounds through membranes. ${ }^{45}$ Interestingly, these inhibitors can be classified, according to their chemical nature, into nucleosides, peptides and non-nucleoside-non-peptides.

Nucleoside MraY inhibitors. These arrays of small molecules have effectively inhibited MraY, for example mureidomycin $\mathrm{A},{ }^{47}$ the first-in-class, muraymycin, tunicamycin and mureidomycin. ${ }^{48-53}$ Chemically, these peptidyl-nucleoside compounds share a common structural feature: a uridine or dihydrouridine skeleton. This particular sub-structure is a key element in their MraY inhibitory properties, which are backed by their ability to recognize and competitively bind to UDP-Mpp binding sites on $\operatorname{MraY}^{\mathbf{4 8 , 5 2 , 5 4 , 5 5}}$ For further information, the SAR details of this group have been reviewed by $\mathrm{T}$. D. Bugg et al. ${ }^{56}$ Unfortunately, the poor physicochemical properties are a perennial limitation that has prevented any further clinical development.

Peptide MraY inhibitors. Amphomycin is a lipopeptide antibiotic that was isolated following the fermentation of Streptomyces canus in 1953. It is a non-competitive inhibitor of MraY, forming a complex with the undecaprenyl phosphate in the presence of calcium ions; hence it prevents the enzymatic reaction. ${ }^{57}$ Notably, amphomycin is active against Grampositive cocci with $\mathrm{MIC}_{50}$ values ranging between 2 and $4 \mu \mathrm{g}$ $\mathrm{ml}^{-1}$ against MSSA and MRSA. 
The second member of this family is protein E, which is produced by the bacteriophage $\varphi \mathrm{X}-174$, and amassed mainly from lipophilic amino acids. ${ }^{5,59}$ Both peptide inhibitors have no clinical value as a result of their unsuitable physicochemical and pharmacokinetic behaviors.

Others (non-nucleoside-non-peptide MraY inhibitors). Unlike nucleoside and peptide inhibitors, articles reporting small molecule MraY inhibitors are very scarce. Bristol-Myers Squibb published the results of a program it launched, intending to screen a large internal library against purified MraY and MruG.$^{60}$ The results, in general, were not encouraging enough to escalate this project to the pre-clinical phase. Briefly, two compounds, BMS-185937 and BMS-187979, displayed antimicrobial potency but with considerable cytotoxicity, which disqualified them from further consideration. Additionally, a third lead, BMS-190134, was an analogue to the undecaprenyl phosphate substrate of MraY; however, its lack of antibacterial activity in vitro led to the termination of this lead as well. Furthermore, the natural product isolate BMS304245 also suffered from the same drawback; i.e. a lack of sufficient antimicrobial activity.

2.3.2.3. Remarks. Notably, the MraY enzyme belongs to a superfamily of proteins called PNPTs (polyribonucleotide nucleotidyltransferases), which also includes a mammalian protein (called GPT), which is used as a post-translational glycosylation catalyst and shares some structural similarities with MraY. Therefore, cross-toxicity against both bacterial and host cells is highly expected with all MraY inhibitors. Consequently, tunicamycin is a useless antibiotic because of its powerful inhibitory activity against human GPT. ${ }^{\mathbf{4 7 , 6 1}}$ Likewise, amphomycin can complex with eukaryotic lipid carriers. ${ }^{62,63}$ Thus, differences in binding features, as established by G. Brändén's group, have to be taken into consideration. ${ }^{64}$

\subsection{Targeting cytoplasmic steps}

2.4.1. Biological importance. The biosynthetic pathway of peptidoglycan is an intricate two-stage process. The first stage, which happens in the cytoplasm, is the construction of the monomeric building block $N$-acetylglucosamine- $N$-acetylmuramyl pentapeptide. The first step in this pathway is the transfer of an enolpyruvate residue from phosphoenolpyruvate to position 3 of UDP- $N$-acetylglucosamine. This reaction is catalysed by MurA, which existed as one copy in Gram-negative bacteria and two copies in Gram-positive as a result of gene duplication. ${ }^{65}$ This reaction is followed by the MurB-catalysed reduction of the enolpyruvate moiety to D-lactate, yielding UDP- $N$-acetylmuramate. A sequence of ATP-dependent amino-acid ligases (MurC, MurD, MurE and MurF) catalyse the stepwise addition of the pentapeptide side-chain to the newly reduced D-lactyl group, resulting in the formation of UDP- $N$-acetylmuramyl pentapeptide.

2.4.2. Inhibitors of enolpyruvyl transferase MurA

2.4.2.1. Natural product leads. • Cnicin 7 is isolated from artichoke and blessed thistle. ${ }^{66}$ While it exerts its activity through covalently binding to the thiol group of Cys115, it is thought that the unsaturated ester side chain is essential to its activity from a structure-activity relationship (SAR) study. ${ }^{67}$

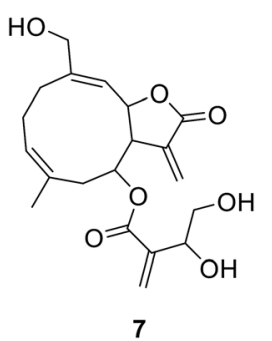

- Fosfomycin $\mathbf{8}$ is a phosphoenolpyruvate analogue produced by Streptomyces fradiae; moreover, it alkylates the active site Cys115 of MurA, causing bactericidal activity. ${ }^{68}$

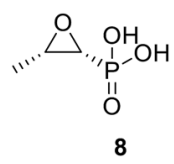

Tuliposide B 9 is a secondary metabolite occurring in tulip anthers. The hydroxyl group of these compounds was found to be crucial for the anti-bacterial activities of tulipaline $B$ and its analogues. ${ }^{69}$

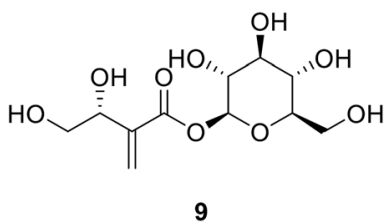

2.4.2.2. Structure-based design. • By screening a chemical library from the Johnson Pharmaceutical Research Institute, a pyrazolopyrimidine, (RWJ-110192) 10, and a purine analogue, (RWJ-140998) 11, were found to be active against Escherichia coli, with $\mathrm{IC}_{50}$ values ranging from $0.2 \mu \mathrm{M}$ to 0.9 $\mu \mathrm{M}$, and showed lower inhibitory activity against Staphylococcus aureus. ${ }^{70}$<smiles>Cc1cc(C)n2[nH]c(=O)c(Cl)c2n1</smiles><smiles>Cn1c2c(c(=O)[nH]c1=O)N1CCCCCSC1N2</smiles>

11

- 5-Sulfonoxy-anthranilic acid derivatives were obtained using HTS. T6361 12 and T6362 13 are known as competitive inhibitors of MurA, with a $K_{\mathrm{i}}$ value of $16 \mu \mathrm{M}^{71}$ 
<smiles>[R]C(C(=O)O)N(C)C(=O)c1cc(OS(=O)(=O)c2cccc3ccccc23)ccc1NS(=O)(=O)c1cccc2ccccc12</smiles>

$12 \mathrm{R}=-\mathrm{CH}_{2} \mathrm{COOH}$ $13 \mathrm{R}=-\mathrm{CH}_{2} \mathrm{CH}_{2} \mathrm{COOH}$

- The 2-aminotetralone $\mathbf{1 4}$ demonstrated antibacterial activity against Staphylococcus aureus and Escherichia coli, with MICs of 17 and $3.13 \mu \mathrm{g} \mathrm{ml}^{-1}$, respectively. $\alpha$-Aminoketone is responsible for the inhibitory activity and evidence has been provided to support its covalent mode of action, involving the C115 thiol group of MurA/MurZ. ${ }^{72}$<smiles>COc1cc2c(cc1OC)C(=O)C(N1CCN(CCO)CC1)CC2</smiles>

14

- The di-bromo substituted nitrovinylfuran 15 has broadspectrum antibacterial activity, via the inhibition of MurA in $E$. coli, $P$. aeruginosa and $S$. aureus, in the low micromolar concentration range. ${ }^{73}$<smiles>O=[N+]([O-])C(Br)=Cc1ccc(Br)o1</smiles>

15

- The benzothioxalone series was found to have potent MurA inhibitory activity, with $\mathrm{IC}_{50}$ values between $0.25 \mu \mathrm{M}$ and $18.54 \mu \mathrm{M}$. Compound 16 has an $\mathrm{IC}_{50}$ value towards MurA of $E$. coli of $0.28 \mu \mathrm{M}$. This inhibition of MurA was irreversible. $^{74}$<smiles>O=c1oc2c(Cl)cc(O)c(Cl)c2s1</smiles>

16

2.4.2.3. Remarks. It should be noted that, because they have one copy of the MurA gene, Gram-negative bacteria are more susceptible to MurA inhibitors, unlike Gram-positive bacteria, which may show resistance as a result of gene duplication.

2.4.3. Inhibitors of the reductase MurB

2.4.3.1. Structure-based design. - The imidazolinone 17 showed antibacterial activity against $S$. aureus. ${ }^{75}$

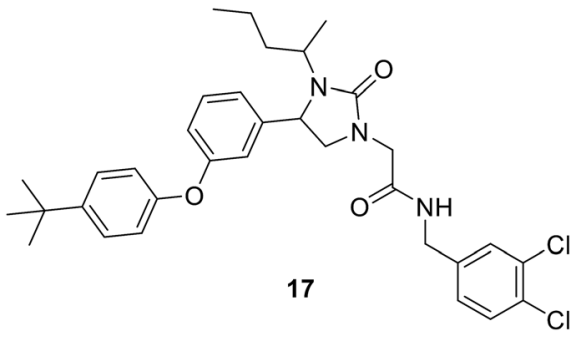

- 3,5-Dioxopyrazolidine inhibitors of MurB were obtained (18 and 19) with $\mathrm{IC}_{50}$ values of $4-10 \mu \mathrm{M}$. Antibacterial activities were shown by these compounds against Gram-positive bacteria, including methicillin-resistant $S$. aureus, vancomycin-resistant Enterococcus faecalis, and penicillin-resistant Streptococcus pneumonia. $^{76}$<smiles>O=C(Nc1ccc(Cl)cc1Cl)C1C(=O)N(c2ccc(Cl)cc2)C(=O)N1c1ccc(Cl)cc1</smiles>

18<smiles>O=C(Nc1c(Cl)cc(Cl)cc1Cl)C1C(=O)N(c2ccc(Cl)cc2)C(=O)N1c1ccc(Cl)cc1</smiles>

19

- A 4-thiazolidinone derivative, 20, was synthesized and evaluated for its ability to inhibit the bacterial enzyme MurB. Compound 20 has an $\mathrm{IC}_{50}$ value of $7.7 \mu \mathrm{M}^{.7}$

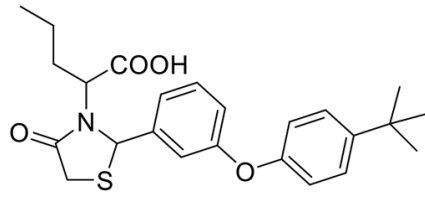

20

- A series of pyrazolidine-3,5-dione (21) and 5-hydroxy-1Hpyrazol-3(2H)-one inhibitors of $E$. coli MurB have been synthesized. The 5-hydroxy-1 $H$-pyrazol-3(2H)-ones showed low micromolar $\mathrm{IC}_{50}$ values versus $E$. coli MurB and sub-micromolar minimum inhibitory concentrations (MICs) against Staphylococcus aureus, Enterococcus faecalis, Streptococcus pneumoniae, and $E$. coli. Docking studies produced several binding orientations for these molecules at the MurB active site. Improvements in MIC values towards MurB are correlated with the increasing lipophilicity of the C-4 substituent of the 5-hydroxy- $1 H$-pyrazol$3(2 H)$-one core. ${ }^{78}$ 
<smiles>CCCCC1(C)C(=O)N(c2ccc(Cl)cc2)N(c2ccc(Cl)cc2)C1=O</smiles>

- Phenylthiazolyl urea and carbamate derivatives were synthesized for evaluation as new inhibitors of bacterial cellwall biosynthesis. Many of them demonstrated good activity against MurA and MurB in Gram-positive bacteria such as MRSA, VRE and PRSP. 3,4-Difluorophenyl 5-cyanothiazolylurea 22 with a clog $P$ value of 2.64 demonstrated antibacterial activity against both Gram-positive and Gram-negative bacteria. ${ }^{77}$<smiles>N#Cc1cnc(NC(=O)Nc2ccc(F)c(F)c2)s1</smiles>

2.4.4. Inhibitors of the ATP-dependent ligase MurC

2.4.4.1. Results of high-throughput screening (HTS). • A series of benzofuran acyl-sulfonamides was identified as a potential lead. Compound 23 inhibited Escherichia coli MurC with an $\mathrm{IC}_{50}$ value of $2.3 \mu \mathrm{M}$, exhibiting time-dependent partially reversible inhibition. ${ }^{79}$<smiles>Cc1ccc(C(=O)NS(=O)(=O)c2ccc(-c3cc4cc(-c5ccccc5)ccc4o3)cc2)s1</smiles>

- The quinoxaline inhibitor 24 competes with ATP; experiments indicated that it was a competitive inhibitor of ATP, binding to the MurC enzyme. ${ }^{\mathbf{8 0}}$<smiles>CC(Oc1nc2ccccc2nc1N)c1ccccc1</smiles>

- Benzylidene rhodanines inhibit $M u r C$ with $\mathrm{IC}_{50}$ values ranging from $12 \mu \mathrm{M}$ to $27 \mu \mathrm{M}$, with whole-cell activity against Gram-positive MRSA but not against Gram-negative E. coli. Compound 25 showed the best MIC value against MRSA of 31 $\mu \mathrm{M}^{81}$<smiles>O=C1NC(=S)C/C1=C\c1cc([N+](=O)[O-])ccc1SCc1ccc(Cl)cc1</smiles>

- $N$-Benzylidenesulfonohydrazide-based compounds, e.g. compound 26, possess inhibitory activity against both MurC and MurD enzymes, with $\mathrm{IC}_{50}$ values of $27 \mu \mathrm{M}$ and $43 \mu \mathrm{M}^{82}$<smiles>O=C(Nc1ccccc1/C=N/NS(=O)(=O)c1ccc2ccccc2c1)c1ccc([N+](=O)[O-])cc1</smiles>

- Compounds with an $N$-acylhydrazone scaffold were characterized as a new class of inhibitors of MurC and MurD from E. coli. Compound 27 has $\mathrm{IC}_{50}$ values of $123 \mu \mathrm{M}$ and 230 $\mu \mathrm{M}$ against MurC and $M u r D$, respectively, and 28 is selective against $M u r C$ with an $\mathrm{IC}_{50}$ value of $32 \mu \mathrm{M} .^{83}$<smiles>O=C(N/N=C/c1ccc(O)c(O)c1O)c1n[nH]c2ccccc12</smiles>

27<smiles>O=C(N/N=C/c1ccc(O)c(O)c1O)c1cnc(-c2ccccc2)s1</smiles>

28

2.4.5. Inhibitors of the ligase MurD. Peptides from phage-display libraries against MurD and MurE were found to inhibit both enzymes, with $\mathrm{IC}_{50}$ values ranging from $140 \mu \mathrm{M}$ to $1.5 \mathrm{mM}$, respectively. These peptides represent a starting point for the design of peptidomimetic lead compounds. Furthermore, $9 H$-xanthene derivative inhibitors have been discovered through the structure-based virtual screening of 1990 compounds from the National Cancer Institute. ${ }^{84}$<smiles>O=C(O)c1c(Br)c(Br)c(Br)c(Br)c1C1c2ccc(O)cc2Oc2cc(O)ccc21</smiles>

- Glutamic acid surrogate-benzene-1,3-dicarboxylic acid derivatives were discovered through virtual screening. Compound $\mathbf{3 0}$ is the most potent, with an $\mathrm{IC}_{50}$ value of $270 \mu \mathrm{M}^{85}$ 
<smiles>O=C(O)c1cc(C(=O)O)cc(-c2ccc(/C=C3\SC(=S)N(c4ccc5c(c4)OCO5)C3=O)o2)c1</smiles>

- Naphthalene- $N$-sulfonyl-D-glutamic acid derivatives were synthesized and screened against MurD from E. coli because of the high binding affinity of D-Glu toward MurD. They displayed $\mathrm{IC}_{50}$ values ranging from 80 to $600 \mathrm{mM}^{86}$

- 5-Benzylidenethiazolidin-4-ones (31 and 32) with lowmicromolar affinity against MurD have been discovered. Remarkably, the thiazolidine-2,4-dione heterocyclic ring binds at the site where the uracil ring of the natural substrate UDPMurNAc-Ala binds. ${ }^{87}$<smiles>O=C(O)CC[C@H](NC(=O)c1ccc(CNc2cccc(/C=C3\SC(=S)NC3=O)c2)cc1)C(=O)O</smiles>

31,32

- Phosphinate compounds were designed and synthesized as inhibitors of the D-glutamic acid-adding enzyme MurD from Escherichia coli. Compounds $\mathbf{3 3}$ and $\mathbf{3 4}$ both had $\mathrm{IC}_{50}$ values near $100 \mu \mathrm{M}^{88}$<smiles>CC(N[C@@H](C)C(=O)N[C@@H](C)P(=O)(O)CC(CCC(=O)O)C(=O)O)P(=O)(O)Cc1ccc([N+](=O)[O-])cc1</smiles><smiles>CC(NC(=O)/C=C/c1ccc2c(c1)OCO2)P(=O)(O)CC(CCC(=O)O)C(=O)O</smiles>

2.4.6. Inhibitors of MurE. - As a natural product, 3methoxynordomesticine (an aporphine alkaloid) 35, which is isolated from a Columbian plant, acts as an inhibitor of $\mathrm{Myco}$ bacterium tuberculosis MurE. ${ }^{89}$<smiles>c1cc2c3c(c1)-c1cc4c(cc1C[C@H]3NCC2)OCO4</smiles>

- Phosphinates also could inhibit MurE via MurD, with an $\mathrm{IC}_{50}$ value of $1.1 \mu \mathrm{M} .^{90}$

- Peptide inhibitors were discovered; the protein $M u r E \mathrm{p}_{1}$ could inhibit MurE with an $\mathrm{IC}_{50}$ value of $500 \mu \mathrm{M}$. This inhibition proved to be time-dependent and was reversed via the addition of UDP-MurNAc-Ala-Glu during the pre-incubation step. ${ }^{91}$

- Sulfonamides that are similar to inhibitors of MurD can inhibit MurE; e.g., compound 36 has an $\mathrm{IC}_{50}$ value of $181 \mu \mathrm{M}$.

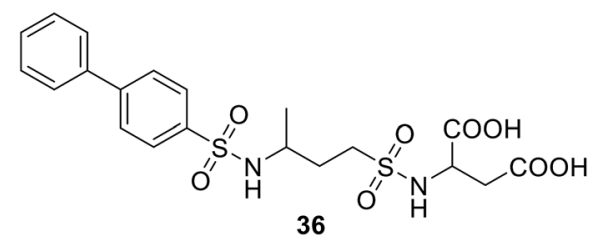

2.4.6.1. Remarks. There is a variation between Grampositive and Gram-negative bacteria regarding the MurE substrate. In most Gram-positive bacteria, the MurE substrate should contain $\mathrm{L}$-lysine as the third amino acid in the peptide, while it could be meso- $\mathrm{A}_{2} \mathrm{pm}$ in Gram-negative bacteria. ${ }^{92,93}$ As MurE is highly sensitive to the amino acid, this difference between the two types of bacteria will change the nature of MurE inhibitors regarding how each bacteria is targeted.

2.4.7. Inhibitors of MurF. - 1,3,5-Triazine-based compounds were discovered via structure-based virtual screening with MurF and subsequent hit optimization, e.g. compound $37 .{ }^{94}$<smiles>OCCc1ccccc1Nc1nc(Cl)nc(Cl)n1</smiles>

- A thiazolylaminopyrimidine series of MurF inhibitors from E. coli was identified in 2006 by Johnson \& Johnson, with the use of an Mpl-based in vitro assay. The most potent compound from this series was compound 38 , with an $\mathrm{IC}_{50}$ value of $2.5 \mu \mathrm{M}{ }^{95}$

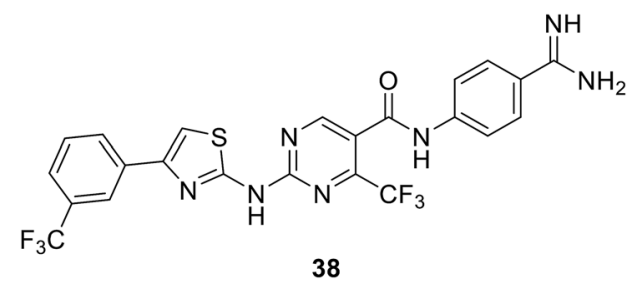

2.4.8. Targeting undecaprenyl pyrophosphate phosphatase (UppP)

2.4.8.1. The biological importance of UppP. Unlike Gramnegative bacteria, undecaprenyl pyrophosphatase phosphate (UppP) is the sole enzyme attributed to the biosynthesis of undecaprenyl phosphate (Up OR C55-P) in Gram-positive bacteria, except in Bacillus subtills where the protein $B c r C$ shares this function. ${ }^{96}$ Unfortunately, in Gram-negative bacteria, it is not just UppP but 3 other genes that are the 


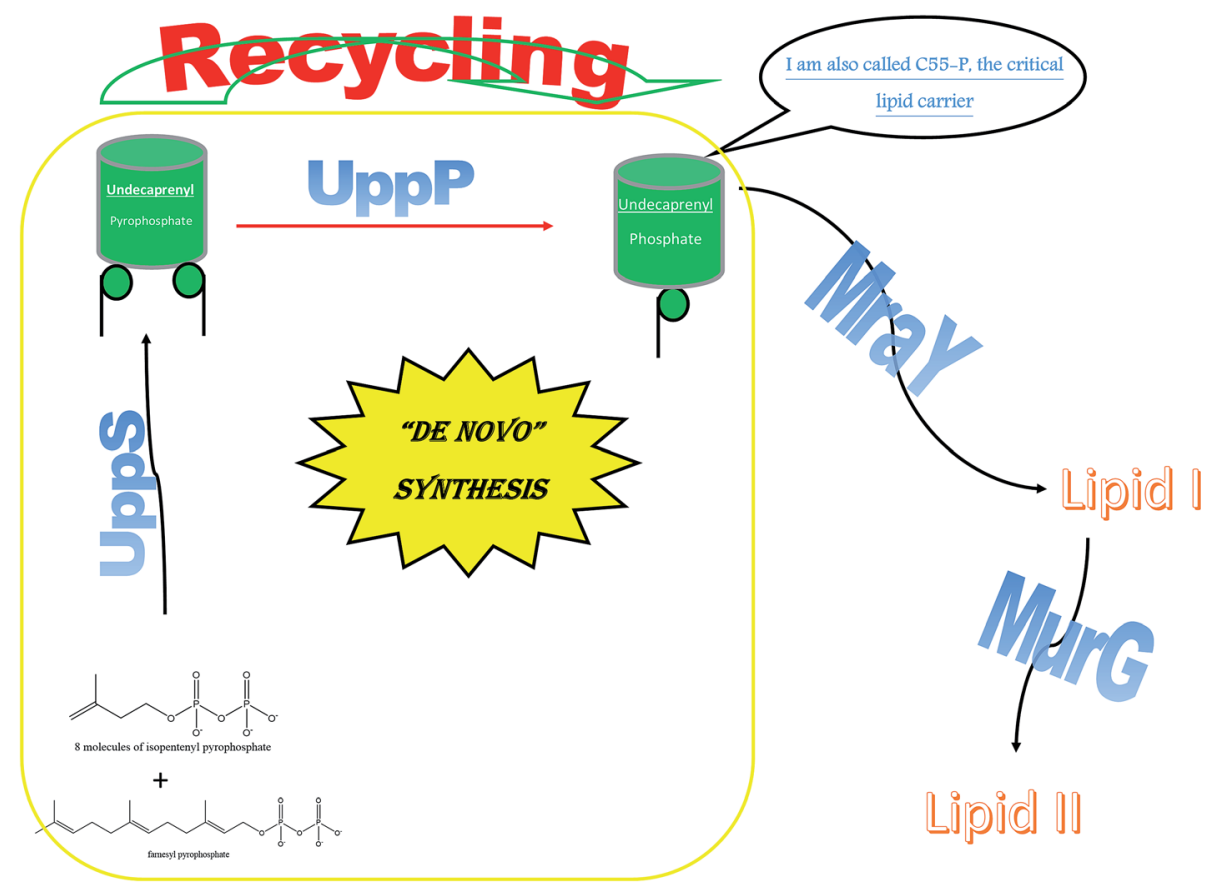

Fig. 3 A diagram emphasizing the essential role of UppP.

chief architects of Up biosynthesis: pgpB, ybgG and lpxT. This makes UppP a less potent target for Gram-negative bacteria. ${ }^{97}$ Up is deemed a vital lipid carrier, as with $M r a Y$ and $M u r G$, which produce lipid I and lipid II, respectively.

Interestingly, the phosphatase enzyme is essential for the two paths of Up production, synthesis and recycling, which suggests that phosphatase is a necessity for cell viability. ${ }^{98}$ To generate the monophosphate form of Und-P, the cell implements the following system: de novo synthesis through the condensation of 8 molecules of isopentenyl pyrophosphate and farnesyl pyrophosphate using the undecaprenyl pyrophosphate synthetase to form undecaprenyl pyrophosphate. This is followed by the cell using the phosphatase enzyme to generate the monophosphate Up. ${ }^{99}$ Moreover, Upp released during vital processes in the cell is recycled to Up using the phosphatase enzyme. Hence, UppP is one of the key enzymes in peptidoglycan biosynthesis, as shown in Fig. 3 .
2.4.8.2. UppP inhibitors. Recently, UppP became a new potential target for antibiotic development, including a focus on the multi-drug resistant $S$. aureus. This was started by GlaxoSmithKline who, for the first time, discovered UppP inhibitors via utilizing an enzyme-based assay system that measured the inorganic phosphate (Pi) released in the enzymatic reaction of the UppP system, and a cell-based assay which analyzed the incorporation of ${ }^{14} \mathrm{C}$ isopentenyl pyrophosphate (IPP). However, their active structures were undisclosed. ${ }^{100}$ The Novartis group studied a pharmacophore model of a co-crystal structure of UppP with a natural substrate at the active site of the enzyme, which successfully led to the discovery of the tetramic acid derivative $\mathbf{3 9}$ as a potent inhibitor of Staphylococcus pneumonia Upp synthase. ${ }^{101}$ Kuo C. et al. ${ }^{102}$ also conducted virtual screening based on the crystal structure of Helicobacter pylori Upp synthase and discovered the bis-sulfonyl-containing compound BTB06061 40, a potent and selective inhibitor of $H$.<smiles>O=C(Nc1ccc(C2CCCCC2)cc1)C1=C(O)CC(c2ccccc2)NC1=O</smiles>

39

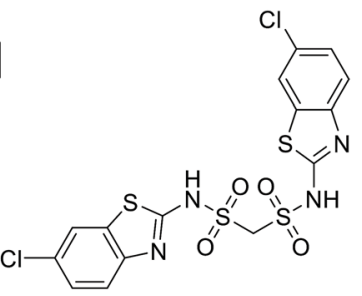

40<smiles>NS(=O)(=O)c1cccc(-c2ccc(C3Nc4ccccc4-c4nc5ccccc5n43)o2)c1</smiles>

41

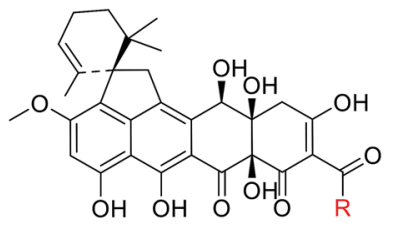


pylori Upp synthase. ${ }^{102}$ Furthermore, Durrant et al. studied a docking model of substrates/inhibitors of Upp synthase based on the X-ray structures of Upp synthase-substrate (for example, tried to explain how these inhibitors could bind to the UppP target through obtaining crystal structures of 47-54 and 56 bound to Escherichia coli UppP.<smiles>CCCCCCOc1cccc(CCNC(=O)C=C(O)C(=O)O)c1</smiles><smiles>CCCCCCCCCOc1cccc(C(=O)Nc2ccc([N+](=O)[O-])cc2C(=O)O)c1</smiles><smiles>CCCCCCCCOc1cccc(COc2ccc(Br)cc2P(=O)(O)O)c1</smiles><smiles>CCCCCCCCCCOc1cccc(C(=O)C=C(O)C(=O)O)c1</smiles><smiles>NCCc1cc(Br)cc(C#Cc2cccc(C#Cc3cc(Br)cc(CCN)c3)c2)c1</smiles>

farnesyl diphosphate)/inhibitor (such as bisphosphonate drugs) complexes, which led to the development of the nonbisphosphonate derivative HTS04781 41, which has potent inhibitory activity against $S$. aureus Upp synthase.$^{103}$ Recently, the same group reported two new structurally related compounds named spirohexaline (42) and viridicatumtoxin (43) as UppP inhibitors isolated from the culture broth of Penicillium brasilianum FKI-3368. ${ }^{103,104}$ These compounds have a hexacycline structure, with a tetracyclic ring fused with a spirobicyclic ring.

Others have reported the discovery of several inhibitors of UppS, comprising bisphosphonates such as BPH-629 $\mathbf{4 4}^{\mathbf{1 0 5}}$ and tetramic acids such as $\mathbf{4 5 ,},{ }^{101}$ as well as diketoacids such as $\mathbf{4 6},{ }^{\mathbf{1 0 6}}$ and benzoic acids such as $47 .{ }^{107}$ Based on HTS, ${ }^{107}$ Durrant et al. produced a series of benzoic (48-51), phosphonic acid (52), and diketoacid (53) compounds with activity against UppS. Furthermore, they discovered several potent cationic inhibitors 54-56, which was unexpected from both a computational and experimental perspective, as these compounds do not mimic the (anionic) FPP substrate and the UppP mechanism is not thought to involve carbocation intermediates. ${ }^{108}$ Therefore, they
2.4.8.3. Phenylthiazoles as a novel class of dual UppP and UppS inhibitors. Phenylthiazoles were reported as a new scaffold with wide antimicrobial activity against multidrug-resistant Gram-positive strains, including MRSA, VRSA and VRE. ${ }^{109}$ This class of antimicrobials exhibited a selective advantage over vancomycin in terms of the rate of elimination of MRSA cells. ${ }^{109,110}$ This criteria is clinically important, as it would affect the size of the dosing regimen necessary for patients. ${ }^{\mathbf{1 1 1}, \mathbf{1 1 2}}$

Through the more than 400 published phenylthiazole derivatives, ${ }^{\mathbf{1 1 0 , 1 1 3 - 1 2 6}}$ the SAR of this class of compounds has become well defined (Fig. 4). In brief, the presence of a lipophilic tail and a cationic nitrogenous head is essential for the antimicrobial activities.

The main drawbacks of the earliest discovered phenylthiazoles were their ultra-short half-lives, ${ }^{118}$ which did not exceed the limit of $30 \mathrm{~min}$, and rapid hepatic elimination rates. Incorporating the imine bond of $1^{\text {st }}$ generation phentylthiazoles within a pyrimidine ring yielded $2^{\text {nd }}$ generation analogues with enhanced metabolic stability $\left(t_{1 / 2}>8 \mathrm{~h}\right) .{ }^{\mathbf{1 2 4}}$ So far, the promising antibacterial potencies of $1^{\text {st }}$ and $2^{\text {nd }}$ generation 


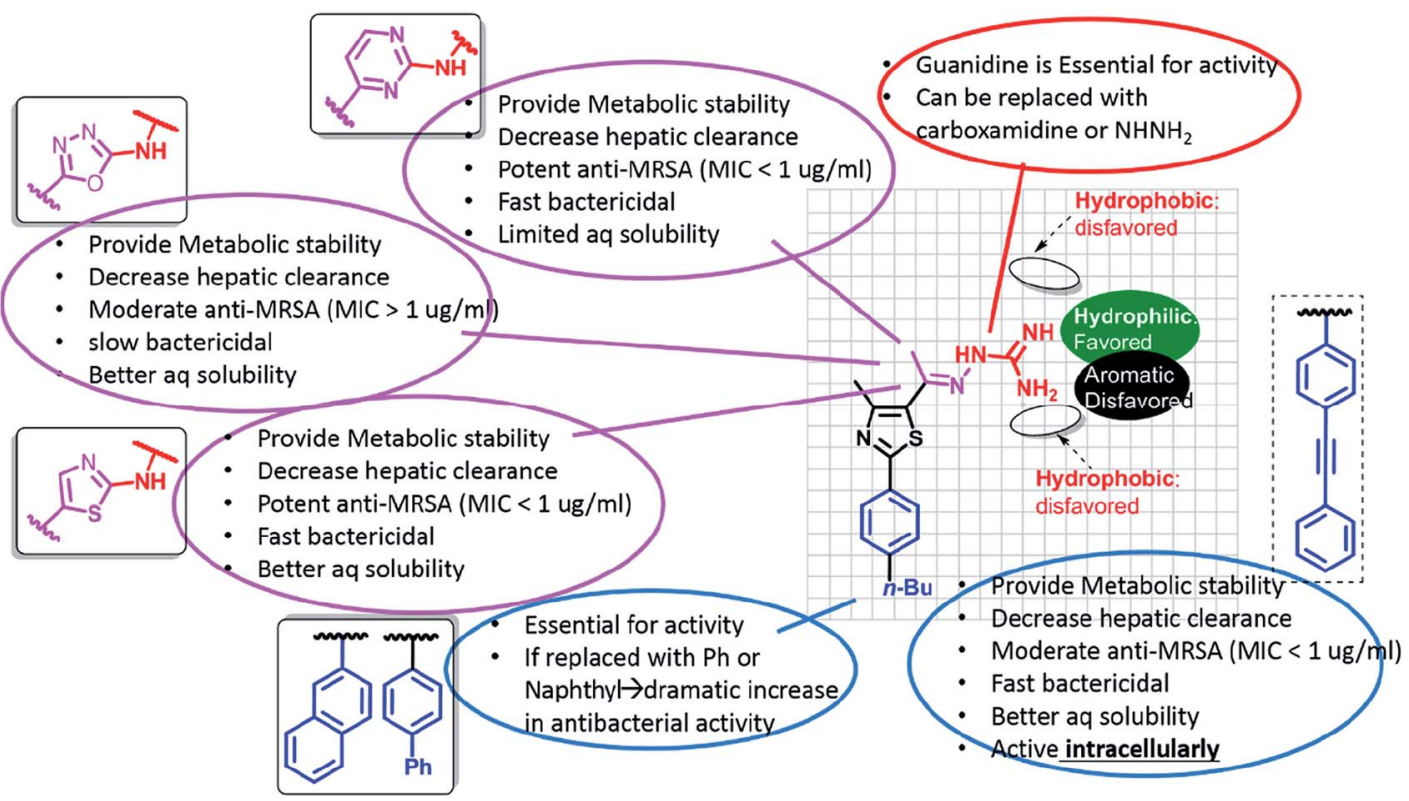

Fig. 4 The SAR of phenylthiazole antibiotics.

phentylthiazoles has been offset by their limited activity against intracellular bacterial pathogens, similar to vancomycin and linezolid. Fine tuning the size and polar surface area of the linking heteroaromatic ring provided $3^{\text {rd }}$ generation PTs with balanced properties that allow them to cross cell barriers and accumulate intracellularly in sufficiently lethal concentrations, while maintaining the metabolic stability and rapid bactericidal attributes (Fig. 5). ${ }^{113}$

Later on, a detailed metabolite analysis was completed and this indicated the presence of an additional metabolic soft spot at the butyl benzylic carbon. ${ }^{125}$ Addressing this limitation, replacing the methylene soft spot with oxygen ${ }^{125}$ or acetylenyl ${ }^{114}$ moieties or undergoing replacement with $t$-butyl, ${ }^{117}$ has yielded phenylthiazoles with even more pronounced stability with respect to the hepatic metabolism (Fig. 6).

Interestingly, at the time of the first discovery of phenylthiazoles, the antibacterial mechanism of action was unknown. Later on, transposon mutagenesis studies conducted by our group suggested three possible antibacterial targets: $Y u b A, Y u b B$ (undecaprenyl diphosphate phosphatase (UppP)) and YubD. Using a direct biochemical assay, the lead phenylthiazole inhibited UppP with an $\mathrm{IC}_{50}$ value of $6 \mu \mathrm{M}$. It also inhibited another enzyme involved in PG biosynthesis called undecaprenyl diphosphate synthase $\left(\mathrm{IC}_{50}=19 \mu \mathrm{M}\right) \cdot{ }^{121}$ More importantly, the inhibitory activity of the phenylthiazole lead compound was tested against human FPPS (HsFPPS) and there was no inhibition of HsFPPS.

2.4.8.4. Remarks. The multitarget inhibition mode of action exhibited by phenylthiazoles for both UppP and UppS, the two adjacent proteins in the cell wall biosynthetic pathway (Fig. 3), may contribute to the inability of MDR-bacterial cells to develop rapid resistance to many members of the phenylthiazole family, even after 14 passages. ${ }^{110,117,126}$

\section{$1^{\text {st }}$ Generation}
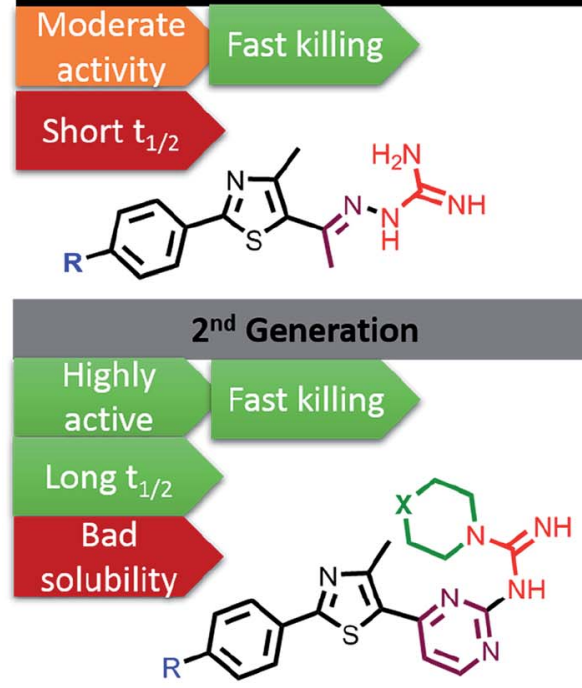

$\mathrm{X}=\mathrm{NMe}, \mathrm{O}$

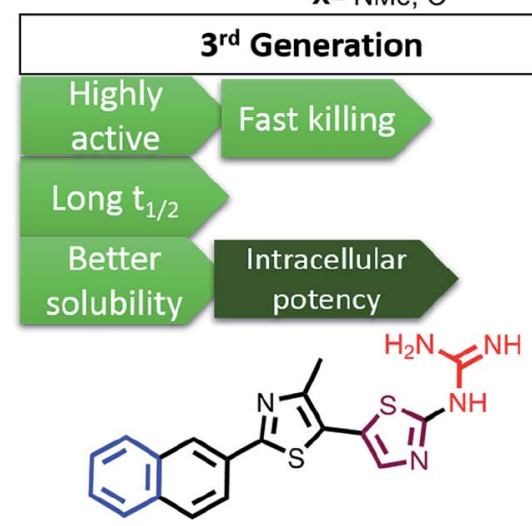

Fig. 5 Different generations of phenylthiazole antibiotics with their associated antimicrobial, physicochemical and pharmacokinetic properties. 
<smiles>CCCC1(CC)CCCCC1(CC)c1ccc(-c2nc(C)c(/C(C)=N/NC(=N)N)s2)cc1</smiles>

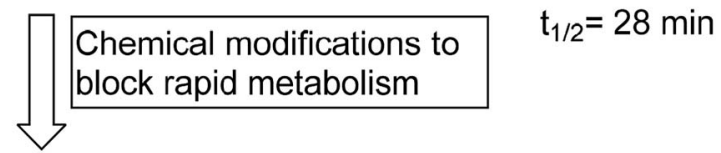<smiles>[R]Oc1ccc(-c2nc(C)c(/C(C)=N/NC(=N)N)s2)cc1</smiles><smiles>C/C(=N\NC(=N)N)c1sc(-c2ccc(C(C)(C)C)cc2)nc1C</smiles>
$t_{1 / 2}=9 h$<smiles>[R]C#Cc1ccc(-c2nc(C)c(/C(C)=N/NC(=N)N)s2)cc1</smiles>
$t_{1 / 2}=4-8 h$

Fig. 6 The half-lives of different classes of phenylthiazole antibiotics.

\section{Conclusions}

The pharmaceutical industry is still relying on hitting the same bacterial targets over and over. This strategy has strengthened the resistance pathways of pathogenic bacteria. Therefore, in order to limit bacterial resistance and increase the survival rates of newly developed antibiotics, the WHO recommends hitting new bacterial pathways using novel chemical cores that are not recognized yet by any resistance machinery of microorganisms. This review illuminates seven potential targets, all participating in peptidoglycan biosynthesis, that may be considered as highly potent and selective targets for future antibiotics in the global fight against increasing microbial resistance. Following WHO criteria, we recommend that medicinal chemists and medical research centers should discard old scaffolds and targets that are already used in the commercial sphere. Additionally, we urge researchers to investigate more novel microbial targets to enable humanity to face microbial resistance waves.

\section{Conflicts of interest}

There are no conflicts to declare.

\section{Acknowledgements}

This work was funded by the Science \& Technology Development Funds (STDF), Grant \#5334.

\section{References}

1 K. Hiramatsu, Lancet Infect. Dis., 2001, 1, 147-155.

2 P. Wilson, J. Andrews, R. Charlesworth, R. Walesby, M. Singer, D. Farrell and M. Robbins, J. Antimicrob. Chemother., 2003, 51, 186-188.

3 A. Jayol, P. Nordmann, A. Brink, M.-V. Villegas, V. Dubois and L. Poirel, Antimicrob. Agents Chemother., 2017, 61, e01423-17.

$4 \mathrm{WHO}$, Antibacterial agents in clinical development: an analysis of the antibacterial clinical development pipeline, including tuberculosis, World Health Organization, Geneva, 2017, WHO/EMP/IAU/2017.11.

5 W. Vollmer, D. Blanot and M. A. de Pedro, FEMS Microbiol. Rev., 2008, 32, 149-167.

6 L. Gan, S. Chen and G. J. Jensen, Proc. Natl. Acad. Sci. U. S. A., 2008, 105, 18953-18957.

7 P. Giesbrecht, T. Kersten, H. Maidhof and J. Wecke, Microbiol. Mol. Biol. Rev., 1998, 62, 1371-1414.

8 A. Tomasz, Rev. Infect. Dis., 1986, 8, S260-S278.

9 W. P. Hammes and F. C. Neuhaus, Antimicrob. Agents Chemother., 1974, 6, 722-728.

10 B. Ostash and S. Walker, Nat. Prod. Rep., 2010, 27, 15941617.

11 N. A. Caveney, F. K. Li and N. C. Strynadka, Curr. Opin. Struct. Biol., 2018, 53, 45-58.

12 K. J. Stone and J. L. Strominger, Proc. Natl. Acad. Sci. U.S.A., 1971, 68, 3223-3227.

13 S. Batson, C. de Chiara, V. Majce, A. J. Lloyd, S. Gobec, D. Rea, V. Fulop, C. W. Thoroughgood, K. J. Simmons, C. G. Dowson, C. W. G. Fishwick, L. P. S. de Carvalho and D. I. Roper, Nat. Commun., 2017, 8, 1939.

14 T. D. Bugg, D. Braddick, C. G. Dowson and D. I. Roper, Trends Biotechnol., 2011, 29, 167-173.

15 G. Siewert and J. L. Strominger, Proc. Natl. Acad. Sci. U.S.A., 1967, 57, 767-773.

16 A. Derouaux, E. Sauvage and M. Terrak, Front. Immunol., 2013, 4, 78 .

17 A. Bouhss, A. E. Trunkfield, T. D. Bugg and D. MenginLecreulx, FEMS Microbiol. Rev., 2007, 32, 208-233.

18 N. F. Galley, A. M. O'Reilly and D. I. Roper, Bioorg. Chem., 2014, 55, 16-26.

19 C. A. Arias and B. E. Murray, Nat. Rev. Microbiol., 2012, 10, 266-278.

20 J. S. Anderson, M. Matsuhashi, M. A. Haskin and J. L. Strominger, Proc. Natl. Acad. Sci. U.S.A., 1965, 53, 881-889.

21 J. Zuegg, C. Muldoon, G. Adamson, D. McKeveney, G. Le Thanh, R. Premraj, B. Becker, M. Cheng, A. G. Elliott and J. X. Huang, Nat. Commun., 2015, 6, 7719.

22 P. Welzel, Chem. Rev., 2005, 105, 4610-4660.

23 P. Butaye, L. A. Devriese and F. Haesebrouck, Antimicrob. Agents Chemother., 2001, 45, 1374-1378.

24 S. Hentschel, D. Kusch and H. Sinell, Zentralbl. Bakteriol., Parasitenkd., Infektionskrankh. Hyg., Abt. 1: Orig., Reihe B, 1979, 168, 546-561. 
25 R. C. Goldman and D. Gange, Curr. Med. Chem., 2000, 7, 801-820.

26 M. D. Barton, Nutr. Res. Rev., 2000, 13, 279-299.

27 Y. Rebets, T. Lupoli, Y. Qiao, K. Schirner, R. Villet, D. Hooper, D. Kahne and S. Walker, ACS Chem. Biol., 2013, 9, 459-467.

28 M. A. Pfaller, Diagn. Microbiol. Infect. Dis., 2006, 56, 115121.

29 G. Huber, in Mechanism of Action of Antibacterial Agents, Springer, 1979, pp. 135-153.

30 X. Wang, L. Krasnova, K. B. Wu, W. S. Wu, T. J. Cheng and C. H. Wong, Bioorg. Med. Chem. Lett., 2018, 28(16), 27082712.

31 M. J. Sofia, N. Allanson, N. T. Hatzenbuhler, R. Jain, R. Kakarla, N. Kogan, R. Liang, D. Liu, D. J. Silva and H. Wang, J. Med. Chem., 1999, 42, 3193-3198.

32 E. R. Baizman, A. A. Branstrom, C. B. Longley, N. Allanson, M. J. Sofia, D. Gange and R. C. Goldman, Microbiology, 2000, 146, 3129-3140.

33 J. Halliday, D. McKeveney, C. Muldoon, P. Rajaratnam and W. Meutermans, Biochem. Pharmacol., 2006, 71, 957-967.

34 H. W. Shih, Y. F. Chang, W. J. Li, F. C. Meng, C. Y. Huang, C. Ma, T. J. R. Cheng, C. H. Wong and W. C. Cheng, Angew. Chem., Int. Ed., 2012, 51, 10123-10126.

35 H. Kuhn, D. Gutelius, E. Black, C. Nadolny, A. Basu and C. Reid, MedChemComm, 2014, 5, 1213-1217.

36 S. Dumbre, A. Derouaux, E. Lescrinier, A. Piette, B. Joris, M. Terrak and P. Herdewijn, J. Am. Chem. Soc., 2012, 134, 9343-9351.

37 T.-J. R. Cheng, Y.-T. Wu, S.-T. Yang, K.-H. Lo, S.-K. Chen, Y.-H. Chen, W.-I. Huang, C.-H. Yuan, C.-W. Guo and L.-Y. Huang, Bioorg. Med. Chem., 2010, 18, 8512-8529.

38 S.-H. Huang, W.-S. Wu, L.-Y. Huang, W.-F. Huang, W.-C. Fu, P.-T. Chen, J.-M. Fang, W.-C. Cheng, T.-J. R. Cheng and C.-H. Wong, J. Am. Chem. Soc., 2013, 135, 17078-17089.

39 C. M. Gampe, H. Tsukamoto, E. H. Doud, S. Walker and D. Kahne, J. Am. Chem. Soc., 2013, 135, 3776-3779.

40 Y. Wang, F. Y. Chan, N. Sun, H. K. Lui, P. K. So, S. C. Yan, K. F. Chan, J. Chiou, S. Chen and R. Abagyan, Chem. Biol. Drug Des., 2014, 84, 685-696.

41 J. A. Thanassi, S. L. Hartman-Neumann, T. J. Dougherty, B. A. Dougherty and M. J. Pucci, Nucleic Acids Res., 2002, 30, 3152-3162.

42 D. S. Boyle and W. D. Donachie, J. Bacteriol., 1998, 180, 6429-6432.

43 D. Mengin-Lecreulx, L. Texier, M. Rousseau and J. van Heijenoort, J. Bacteriol., 1991, 173, 4625-4636.

44 M. Ikeda, M. Wachi, H. Jung, F. Ishino and M. Matsuhashi, J. Bacteriol., 1991, 173, 1021-1026.

45 Y. Liu and E. Breukink, Antibiotics, 2016, 5, 28.

46 T. Mohammadi, A. Karczmarek, M. Crouvoisier, A. Bouhss, D. Mengin-Lecreulx and T. Den Blaauwen, Mol. Microbiol., 2007, 65, 1106-1121.

47 F. Isono and M. Inukai, Antimicrob. Agents Chemother., 1991, 35, 234-236.

48 T. D. Bugg, A. J. Lloyd and D. I. Roper, Infect. Disord. - Drug Targets, 2006, 6, 85-106.
49 P. E. Brandish, K.-i. Kimura, M. Inukai, R. Southgate, J. T. Lonsdale and T. Bugg, Antimicrob. Agents Chemother., 1996, 40, 1640-1644.

50 P. E. Brandish, M. K. Burnham, J. T. Lonsdale, R. Southgate, M. Inukai and T. D. Bugg, J. Biol. Chem., 1996, 271, 76097614.

51 A. J. Lloyd, P. E. Brandish, A. M. Gilbey and T. D. Bugg, J. Bacteriol., 2004, 186, 1747-1757.

52 M. T. Rodolis, A. Mihalyi, C. Ducho, K. Eitel, B. Gust, R. J. Goss and T. D. Bugg, Chem. Commun., 2014, 50, 13023-13025.

53 M. T. Rodolis, A. Mihalyi, A. O'Reilly, J. Slikas, D. I. Roper, R. E. Hancock and T. D. Bugg, ChemBioChem, 2014, 15, 1300-1308.

54 C. Dini, P. Collette, N. Drochon, J. Guillot, G. Lemoine, P. Mauvais and J. Aszodi, Bioorg. Med. Chem. Lett., 2000, 10, 1839-1843.

55 T. Tanino, B. Al-Dabbagh, D. Mengin-Lecreulx, A. Bouhss, H. Oyama, S. Ichikawa and A. Matsuda, J. Med. Chem., 2011, 54, 8421-8439.

56 T. D. Bugg, M. T. Rodolis, A. Mihalyi and S. Jamshidi, Bioorg. Med. Chem., 2016, 24, 6340-6347.

57 D. K. Banerjee, J. Biol. Chem., 1989, 264, 2024-2028.

58 T. G. Bernhardt, W. D. Roof and R. Young, Proc. Natl. Acad. Sci. U.S.A., 2000, 97, 4297-4302.

59 T. G. Bernhardt, D. K. Struck and R. Young, J. Biol. Chem., 2001, 276, 6093-6097.

60 L. E. Zawadzke, P. Wu, L. Cook, L. Fan, M. Casperson, M. Kishnani, D. Calambur, S. J. Hofstead and R. Padmanabha, Anal. Biochem., 2003, 314, 243-252.

61 J. Yoo, E. H. Mashalidis, A. C. Kuk, K. Yamamoto, B. Kaeser, S. Ichikawa and S.-Y. Lee, Nat. Struct. Mol. Biol., 2018, 25, 217.

62 M. Kang, J. P. Spencer and A. D. Elbein, Biochem. Biophys. Res. Commun., 1978, 82, 568-574.

63 M. S. Kang, J. P. Spencer and A. D. Elbein, J. Biol. Chem., 1978, 253, 8860-8866.

64 J. Hering, E. Dunevall, M. Ek and G. Brändén, Drug Discovery Today, 2018, 1426-1435.

65 W. Du, J. R. Brown, D. R. Sylvester, J. Huang, A. F. Chalker, C. Y. So, D. J. Holmes, D. J. Payne and N. G. Wallis, J. Bacteriol., 2000, 182, 4146-4152.

66 H. Mizuno and T. Usuki, ChemistrySelect, 2018, 3, 17811786.

67 A. Bachelier, R. Mayer and C. D. Klein, Bioorg. Med. Chem. Lett., 2006, 16, 5605-5609.

68 T. D. Bugg, Compr. Nat. Prod. Chem., 1999, 3, 241-294.

69 K. Shigetomi, K. Shoji, S. Mitsuhashi and M. Ubukata, Phytochemistry, 2010, 71, 312-324.

70 E. Z. Baum, D. A. Montenegro, L. Licata, I. Turchi, G. C. Webb, B. D. Foleno and K. Bush, Antimicrob. Agents Chemother., 2001, 45, 3182-3188.

71 S. Eschenburg, M. A. Priestman, F. A. Abdul-Latif, C. Delachaume, F. Fassy and E. Schönbrunn, J. Biol. Chem., 2005, 280, 14070-14075.

72 C. J. Dunsmore, K. Miller, K. L. Blake, S. G. Patching, P. J. F. Henderson, J. A. Garnett, W. J. Stubbings, 
S. E. V. Phillips, D. J. Palestrant, J. D. L. Angeles, J. A. Leeds, I. Chopra and C. W. G. Fishwick, Bioorg. Med. Chem. Lett., 2008, 18, 1730-1734.

73 T. Scholz, C. L. Heyl, D. Bernardi, S. Zimmermann, L. Kattner and C. D. Klein, Bioorg. Med. Chem., 2013, 21, 795-804.

74 K. Miller, C. J. Dunsmore, J. A. Leeds, S. G. Patching, M. Sachdeva, K. L. Blake, W. J. Stubbings, K. J. Simmons, P. J. Henderson and J. De Los Angeles, J. Antimicrob. Chemother., 2010, 65, 2566-2573.

75 J. J. Bronson, K. L. DenBleyker, P. J. Falk, R. A. Mate, H.-T. Ho, M. J. Pucci and L. B. Snyder, Bioorg. Med. Chem. Lett., 2003, 13, 873-875.

76 Y. Yang, A. Severin, R. Chopra, G. Krishnamurthy, G. Singh, W. Hu, D. Keeney, K. Svenson, P. J. Petersen, P. Labthavikul, D. M. Shlaes, B. A. Rasmussen, A. A. Failli, J. S. Shumsky, K. M. K. Kutterer, A. Gilbert and T. S. Mansour, Antimicrob. Agents Chemother., 2006, 50, 556-564.

77 C. J. Andres, J. J. Bronson, S. V. D'Andrea, M. S. Deshpande, P. J. Falk, K. A. Grant-Young, W. E. Harte, H.-T. Ho, P. F. Misco, J. G. Robertson, D. Stock, Y. Sun and A. W. Walsh, Bioorg. Med. Chem. Lett., 2000, 10, 715-717.

78 A. M. Gilbert, A. Failli, J. Shumsky, Y. Yang, A. Severin, G. Singh, W. Hu, D. Keeney, P. J. Petersen and A. H. Katz, J. Med. Chem., 2006, 49, 6027-6036.

79 D. E. Ehmann, J. E. Demeritt, K. G. Hull and S. L. Fisher, Biochim. Biophys. Acta, Proteins Proteomics, 2004, 1698, 167-174.

80 L. E. Zawadzke, M. Norcia, C. R. Desbonnet, H. Wang, K. Freeman-Cook and T. J. Dougherty, Assay Drug Dev. Technol., 2008, 6, 95-103.

81 T. Tomasic and L. P. Masic, Curr. Med. Chem., 2009, 16, 1596-1629.

82 R. Frlan, A. Kovač, D. Blanot, S. Gobec, S. Pečar and A. Obreza, Molecules, 2008, 13, 11.

83 R. Šink, A. Kovač, T. Tomašić, V. Rupnik, A. Boniface, J. Bostock, I. Chopra, D. Blanot, L. P. Mašič and S. Gobec, ChemMedChem, 2008, 3, 1362-1370.

84 S. Turk, A. Kovač, A. Boniface, J. M. Bostock, I. Chopra, D. Blanot and S. Gobec, Bioorg. Med. Chem., 2009, 17, 1884-1889.

85 A. Perdih, A. Kovač, G. Wolber, D. Blanot, S. Gobec and T. Solmajer, Bioorg. Med. Chem. Lett., 2009, 19, 2668-2673.

86 J. Humljan, M. Kotnik, C. Contreras-Martel, D. Blanot, U. Urleb, A. Dessen, T. Šolmajer and S. Gobec, J. Med. Chem., 2008, 51, 7486-7494.

87 N. Zidar, T. Tomašić, R. Šink, V. Rupnik, A. Kovač, S. Turk, D. Patin, D. Blanot, C. Contreras Martel, A. Dessen, M. Müller Premru, A. Zega, S. Gobec, L. Peterlin Mašič and D. Kikelj, J. Med. Chem., 2010, 53, 6584-6594.

88 K. Štrancar, D. Blanot and S. Gobec, Bioorg. Med. Chem. Lett., 2006, 16, 343-348.

89 J. D. Guzman, A. Gupta, D. Evangelopoulos, C. Basavannacharya, L. C. Pabon, E. A. Plazas, D. R. Munoz, W. A. Delgado, L. E. Cuca and W. Ribon, J. Antimicrob. Chemother., 2010, 65, 2101-2107.
90 K. Štrancar, A. Boniface, D. Blanot and S. Gobec, Arch. Pharm., 2007, 340, 127-134.

91 C. Paradis-Bleau, A. Lloyd, F. Sanschagrin, H. Maaroufi, T. Clarke, A. Blewett, C. Dowson, D. I. Roper, T. D. H. Bugg and R. C. Levesque, Biochem. J., 2009, 421, 263-272.

92 D. Mengin-Lecreulx, T. Falla, D. Blanot, J. van Heijenoort, D. J. Adams and I. Chopra, J. Bacteriol., 1999, 181, 59095914.

93 K. H. Schleifer and O. Kandler, Bacteriol. Rev., 1972, 36, 407-477.

94 I. Sosic, B. Stefane and A. Kovac, Heterocycles, 2010, 81, 91115.

95 E. Z. Baum, S. M. Crespo-Carbone, D. Abbanat, B. Foleno, A. Maden, R. Goldschmidt and K. Bush, Antimicrob. Agents Chemother., 2006, 50, 230-236.

96 R. Bernard, M. El Ghachi, D. Mengin-Lecreulx, M. Chippaux and F. Denizot, J. Biol. Chem., 2005, 280, 28852-28857.

97 Y. Li and X. Tian, Immunogenetics, 2016, 1, 2.

98 M. El Ghachi, A. Bouhss, D. Blanot and D. Mengin-Lecreulx, J. Biol. Chem., 2004, 279, 30106-30113.

99 M. Jukic, K. Rozman and S. Gobec, Curr. Med. Chem., 2016, 23, 464-482.

100 H. Li, J. Huang, X. Jiang, M. Seefeld, M. McQueney and R. Macarron, J. Biomol. Screening, 2003, 8, 712-715.

101 S. Peukert, Y. Sun, R. Zhang, B. Hurley, M. Sabio, X. Shen, C. Gray, J. Dzink-Fox, J. Tao and R. Cebula, Bioorg. Med. Chem. Lett., 2008, 18, 1840-1844.

102 C.-J. Kuo, R.-T. Guo, I.-L. Lu, H.-G. Liu, S.-Y. Wu, T.-P. Ko, A. H.-J. Wang and P.-H. Liang, BioMed Res. Int., 2008, 2008, 841312.

103 W. Sinko, C. de Oliveira, S. Williams, A. Van Wynsberghe, J. D. Durrant, R. Cao, E. Oldfield and J. A. McCammon, Chem. Biol. Drug Des., 2011, 77, 412-420.

104 J. Inokoshi, Y. Nakamura, Z. Hongbin, R. Uchida, K.-i. Nonaka, R. Masuma and H. Tomoda, J. Antibiot., 2013, 66, 37-41.

105 R.-T. Guo, R. Cao, P.-H. Liang, T.-P. Ko, T.-H. Chang, M. P. Hudock, W.-Y. Jeng, C. K.-M. Chen, Y. Zhang and Y. Song, Proc. Natl. Acad. Sci. U.S.A., 2007, 104, 1002210027.

106 Y. Zhang, F.-Y. Lin, K. Li, W. Zhu, Y.-L. Liu, R. Cao, R. Pang, E. Lee, J. Axelson and M. Hensler, ACS Med. Chem. Lett., 2012, 3, 402-406.

107 J. D. Durrant, R. Cao, A. A. Gorfe, W. Zhu, J. Li, A. Sankovsky, E. Oldfield and J. A. McCammon, Chem. Biol. Drug Des., 2011, 78, 323-332.

108 Y.-P. Lu, H.-G. Liu and P.-H. Liang, Biochem. Biophys. Res. Commun., 2009, 379, 351-355.

109 H. Mohammad, A. S. Mayhoub, A. Ghafoor, M. Soofi, R. A. Alajlouni, M. Cushman and M. N. Seleem, J. Med. Chem., 2014, 57, 1609-1615.

110 H. Mohammad, A. S. Mayhoub, M. Cushman and M. N. Seleem, J. Antibiot., 2015, 68, 259-266.

111 G. Pankey and L. Sabath, Clin. Infect. Dis., 2004, 38, 864870.

112 G. French, J. Antimicrob. Chemother., 2006, 58, 1107-1117. 
113 I. Eid, M. M. Elsebaei, H. Mohammad, M. Hagras, C. E. Peters, Y. A. Hegazy, B. Cooper, J. Pogliano, K. Pogliano, H. S. Abulkhair, M. N. Seleem and A. S. Mayhoub, Eur. J. Med. Chem., 2017, 139, 665-673.

114 M. M. Elsebaei, H. Mohammad, M. Abouf, N. S. Abutaleb, Y. A. Hegazy, A. Ghiaty, L. Chen, J. Zhang, S. R. Malwal, E. Oldfield, M. N. Seleem and A. S. Mayhoub, Eur. J. Med. Chem., 2018, 148, 195-209.

115 M. Hagras, Y. A. Hegazy, A. H. Elkabbany, H. Mohammad, A. Ghiaty, T. M. Abdelghany, M. N. Seleem and A. S. Mayhoub, Eur. J. Med. Chem., 2018, 143, 1448-1456.

116 M. Hagras, H. Mohammad, M. S. Mandour, Y. A. Hegazy, A. Ghiaty, M. N. Seleem and A. S. Mayhoub, J. Med. Chem., 2017, 60, 4074-4085.

117 A. Kotb, N. S. Abutaleb, M. A. Seleem, M. Hagras, H. Mohammad, A. Bayoumi, A. Ghiaty, M. N. Seleem and A. S. Mayhoub, Eur. J. Med. Chem., 2018, 151, 110-120.

118 H. Mohammad, A. S. Mayhoub, A. Ghafoor, M. Soofi, R. A. Alajlouni, M. Cushman and M. N. Seleem, J. Med. Chem., 2014, 57, 1609-1615.

119 H. Mohammad, P. V. Reddy, D. Monteleone, A. S. Mayhoub, M. Cushman, G. K. Hammac and M. N. Seleem, PLoS One, 2015, 10, e0130385.

120 H. Mohammad, P. V. Reddy, D. Monteleone, A. S. Mayhoub, M. Cushman and M. N. Seleem, Eur. J. Med. Chem., 2015, 94, 306-316.
121 H. Mohammad, W. Younis, L. Chen, C. E. Peters, J. Pogliano, K. Pogliano, B. Cooper, J. Zhang, A. Mayhoub, E. Oldfield, M. Cushman and M. N. Seleem, J. Med. Chem., 2017, 60, 2425-2438.

122 H. Mohammad, W. Younis, H. G. Ezzat, C. E. Peters, A. AbdelKhalek, B. Cooper, K. Pogliano, J. Pogliano, A. S. Mayhoub and M. N. Seleem, PLoS One, 2017, 12, e0182821.

123 H. X. Ngo, K. D. Green, C. S. Gajadeera, M. J. Willby, S. Y. Holbrook, C. Hou, A. Garzan, A. S. Mayhoub, J. E. Posey and O. V. Tsodikov, ACS Infect. Dis., 2018, 1030-1040.

124 M. A. Seleem, A. M. Disouky, H. Mohammad, T. M. Abdelghany, A. S. Mancy, S. A. Bayoumi, A. Elshafeey, A. El-Morsy, M. N. Seleem and A. S. Mayhoub, J. Med. Chem., 2016, 59, 4900-4912.

125 E. Yahia, H. Mohammad, T. M. Abdelghany, E. Fayed, M. N. Seleem and A. S. Mayhoub, Eur. J. Med. Chem., 2017, 126, 604-613.

126 M. ElAwamy, H. Mohammad, A. Hussien, N. S. Abutaleb, M. Hagras, R. A. T. Serya, A. T. Taher, K. A. Abouzid, M. N. Seleem and A. S. Mayhoub, Eur. J. Med. Chem., 2018, 152, 318-328. 